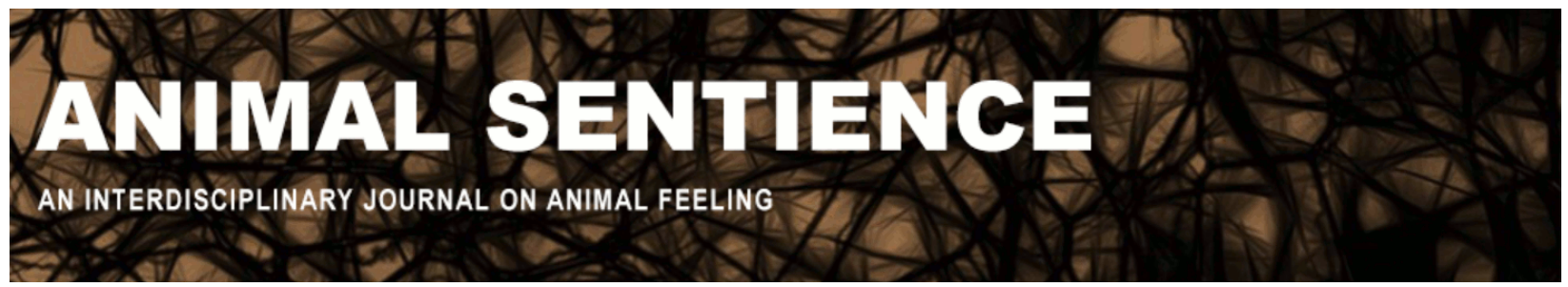

Baker, Liv (2019) To preserve or to conserve?. Animal Sentience 27(7)

DOI: $10.51291 / 2377-7478.1530$

Date of submission: 2019-11-10

Date of acceptance: 2019-12-01

(c) (i)

This article has appeared in the journal Animal

Sentience, a peer-reviewed journal on animal

cognition and feeling. It has been made open access,

free for all, by WellBeing International and deposited

in the WBI Studies Repository. For more information,

please contact

wbisr-info@wellbeingintl.org.

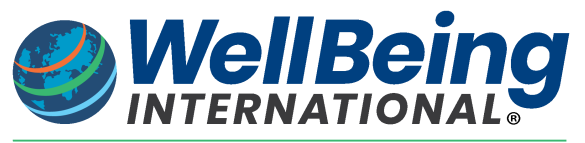

SOLUTIONS FOR PEOPLE, ANIMALS AND ENVIRONMENT 


\title{
To preserve or to conserve?
}

Commentary on Treves et al. on Just Preservation

\section{Liv Baker \\ Animal Behavior and Conservation Program, Hunter College, New York}

\begin{abstract}
Treves et al. propose the notion of trusteeship to help meet our responsibility to nature and individual animals, their homes, cultures, and societies. This proposal is grounded in a realworld framework that reveals how conservation has become distorted by anthropocentrism, human exceptionalism, and ethical hypocrisy.
\end{abstract}

Liv Baker is a conservation behaviorist and an expert in wild animal welfare. Liv's work explores similar patterns of wellbeing seen across the animal kingdom. Her work includes elephants, cetaceans, primates, arachnids, rodents, macropods, and pigs. Liv teaches at Hunter College, CUNY, and is the research director with Mahouts Elephant Foundation, UK. Website

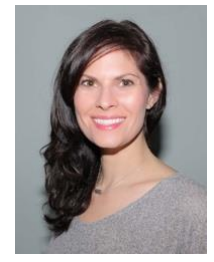

Treves et al.'s (2019) proposal for protecting nature and the non-human world is grounded in the real world. They replace the term 'conservation' with 'preservation' - meaning 'saving for the future' rather than 'maintaining (something) in its original or existing state' - arguing that 'conservation' is beset by anthropocentrism, human exceptionalism, and ethical hypocrisy and that it has long been associated with a utilitarian and instrumental focus on maintaining or restoring nature to an (arbitrary) original or permanent state (e.g., see discourses on Noah's-ark conservation, Harris et al., 2015; the role of zoological societies, Miller et al., 2004; predator-free campaigns on island nations, Russell et al., 2015; Pleistocene rewilding, Rubenstein and Rubenstein, 2016; and non-nativeness, Hettinger, 2012).

To meet our responsibility to nature and to individual animals, their homes, cultures, and societies, Treves et al. propose the idea of trusteeship. This proposal is interesting for both ethical and practical reasons. Conflicts between social ideals and individual goals often impede social progress. Change in the will of society is achieved through pressure at many levels - from the individual to the body politic. Vesting a collective of people with custodianship can embolden them to protect what is in their charge (Craft et al., 2008). Trusteeship may also serve as a bridge between 'moral responsibility and legal accountability' (Bosselmann, 2015) and across the 'empathy gap' between 'us' and 'them.' Human cognition research suggests that we are hardwired to empathize (e.g., de Waal, 2012); but we are also impelled to form exclusive social memberships along such lines as race, religion, gender, socio-economic status, and even alma mater and sports team allegiance (Centola et al., 2007). Such cultural gaps in empathy between members of our own species become an empathy chasm when it comes to our relationship with other species. Arbitrary human notions about what is rare or commonplace, threatening or beautiful can determine an animal's and even an entire species' value for us. 
There is hope, however. Treves et al. cite our evolved capacity to care about and understand the feelings and perspectives of others, across human communities as well as species. Although our evolved need to form social alliances creates in-groups and out-groups, there is flexibility in what defines our identity and whom we identify with. Just Preservation, in discussing 'futurity,' suggests that positioning human well-being alongside non-human well-being will extend our empathy span across generational gaps as well.

\section{References}

Bosslemann, K. (2015) Earth Governance: Trusteeship of the Global Commons. UK: Edward Elgar Publishing Ltd.

Centola, D., González-Avella, JC, Eguíluz, VM, and Miguel, MS. (2007) Homophily, Cultural Drift, and the Co-Evolution of Cultural Groups. Journal of Conflict Resolution, 51(6): 905-929.

Craft, A, Gardner, H, and Claxton, G. (2008) Creativity, Wisdom and Trusteeship. CA: Corwin Press.

de Waal, FBM. (2012) The Antiquity of Empathy. Science, 336(6083): 874-876.

Harris, RMB, Carter, M, Gilfedder, L, Porfirio, LL, Lee, G, and Bindoff, NL. (2015) Noah's Ark Conservation Will Not Preserve Threatened Ecological Communities under Climate Change. PloS One, 10(4): e0124014.

Hettinger, N. (2012) Conceptualizing and Evaluating Non-Native Species. Nature Education Knowledge, 3(10): 7.

Miller, B, Conway, W, Reading, RP, Wemmer, C, Wildt, D, Kleiman, D, Monfort, S, Rabinowitz, A, Armstrong, B, and Hutchins, M. (2004) Evaluating the Conservation Mission of Zoos, Aquariums, Botanical Gardens, and Natural History Museums. Conservation Biology, 18(1): 86-93.

Rubenstein, DR, and Rubenstein, DI. (2016) From Pleistocene to Trophic Rewilding: A Wolf in Sheep's Clothing. PNAS, 113(1): E1.

Russell, JC, Innes, JG, Brown, PH, and Byrom, AE. (2015) Predator-free New Zealand:

Conservation Country. Bioscience, 65(5): 520-525.

Treves, A, Santiago-Ávila, FJ, and Lynn, WS. (2019) Just preservation. Animal Sentience 27(1). 